Research Article

\title{
Purification, Characterization, and Time-Dependent Adsorption Studies of Ghanaian Muscovite Clay
}

\author{
Samuel Tetteh $\mathbb{D}^{1},{ }^{1}$ Andrews Quashie, ${ }^{2}$ and Michael Akrofi Anang $\mathbb{D D}^{1}$ \\ ${ }^{1}$ Chemistry Department, School of Physical Sciences, College of Agriculture and Natural Sciences, University of Cape Coast, \\ Cape Coast, Ghana \\ ${ }^{2}$ Institute of Industrial Research, Council for Scientific and Industrial Research, Accra, Ghana \\ Correspondence should be addressed to Samuel Tetteh; stoshgh2001@yahoo.com
}

Received 16 June 2018; Revised 10 August 2018; Accepted 28 August 2018; Published 18 September 2018

Academic Editor: Amit Bhatnagar

Copyright (c) 2018 Samuel Tetteh et al. This is an open access article distributed under the Creative Commons Attribution License, which permits unrestricted use, distribution, and reproduction in any medium, provided the original work is properly cited.

Three clay samples (E1, E2, and C1) extracted from different parts of Ghana have been purified by sedimentation. The samples were further characterized by powder X-ray diffraction (PXRD), Fourier transform infrared spectroscopy (FT-IR), scanning electron microscopy (SEM), cation exchange capacity (CEC), and point of zero charge $\left(\mathrm{pH}_{\mathrm{pzc}}\right)$. PXRD and FT-IR data revealed the samples to be predominantly muscovite clay with percentages ranging from 82.71 to $91.33 \%$. The surfaces were mostly cationic with $\mathrm{pH}_{\mathrm{pzc}}$ ranging from 5.58 to 6.40. Morphological studies by SEM confirmed the crystalline nature of the surfaces which is suitable for adsorption studies. Time-dependent adsorption studies show that $\mathrm{C} 1$ is a good candidate for the adsorption of chlorophenols, methyl orange, and Eriochrome Black T.

\section{Introduction}

Phenolic compounds are classified among the main raw materials used in industry and photochemical research [1-4]. Phenols are widely used in the production of materials such as pharmaceuticals, dyes, cosmetics, epoxy resins, and adhesives as well as photocells for various applications $[5,6]$. They are the main contaminants in wastewater generated from petroleum refineries, dye- and phenol-producing industries, and general households which use phenol-based disinfectants [7]. Phenols also enter the environment through the use of phenoxy herbicides such as 2,4-dichlorophenoxyacetic acid or 4-chloro2-methylphenoxyacetic acid and also phenolic biocides like pentachlorophenol [8]. These compounds are classified as noxious pollutants because of their toxicity even at low concentrations. The toxicity of phenols and their derivatives include histopathological changes, mutagenicity, and carcinogenicity [9]. Stringent US Environmental Protection Agency (USEPA) regulations have therefore been called for the lowering of phenol content in wastewater to less than $1 \mathrm{mg} / \mathrm{L}$ [10].
Several methods have been employed for the removal of phenolics from aqueous solutions. These techniques can be classified as biological, chemical, or physical [11]. Biodegradation methods, including microbial degradation, fungal decolonization, and bioremediation systems, have been employed in the treatment of industrial effluents, as microorganisms such as yeast, bacteria, and fungi are able to catalyze the breakdown of several organic pollutants into harmless products. However, if not controlled, these microorganisms could contaminate other systems leading to the outbreak of diseases [12] and emission of toxic products [13]. On the other hand, chemical methods such as coagulation, precipitation, flocculation with iron(II)/calcium hydroxide, electrokinetic coagulation, and conventional oxidation methods involving oxidizing agents such as hydrogen peroxide, ozone, and $\mathrm{KMnO}_{4}$ have also been explored for the degradation of phenolics in wastewater [14-16]. Recently, advanced oxidation processes like the Fenton process have also been used $[17,18]$. The Fenton process and related reactions usually involve reactions of peroxides (particularly hydrogen peroxide) with $\mathrm{Fe}(\mathrm{II})$ ions to form reactive oxygen species such as the hydroxyl radical 
(HO) which initiates a series of chain reactions that catalyze the degradation of various organic compounds [19]. This method has been effectively used in wastewater treatment processes for the removal of hazardous organics from wastewater [20]. These methods are not environmentally friendly because the initiated free radical reactions are very difficult to terminate and could affect aquatic life when the effluents are discharged into water bodies. They are also expensive and commercially unattractive.

Several physical methods such as membrane-filtration processes and adsorption techniques are also used in the treatment of wastewater [21]. Adsorption processes involving solid adsorbents are widely used to remove certain pollutants from industrial effluents before final disposal into water bodies. Amongst the solid adsorbents used commercially, activated carbon is widely employed for the removal of a wide variety of phenolic compounds from wastewater because of its large capacity to adsorb phenols $[22,23]$. This can be attributed to its structural characteristics and high porosity which gives it a large surface area [23]. However, there are several challenges which come with the production and use of activated carbon. These include the destruction of vegetation and the generation of harmful gases such as carbon, $\mathrm{CO}$, and NOx which are not environmentally friendly. The regeneration of saturated carbon is also expensive and results in the loss of adsorbent [11].

Natural clay mineral, an environmentally friendly and relatively cheap adsorbent, has been explored for the removal of phenols and dyes from water and wastewater [24]; however, industrial scale application is still limited as a result of lack of specificity of the type of dye for a given clay. Some dyes adsorb strongly onto certain clays, whereas others adsorb poorly. According to Kurniawan et al., the use of chemicals for the surface modification of clay materials improves its adsorption characteristics [25], but these chemicals usually pose serious problems to the environment and usually require expensive waste treatment systems to remove the excess chemicals. Untreated clay samples which have been successfully applied in the adsorption of dyes from wastewater include bentonite [26-29], kaolinite [30], attapulgite [31], montmorillonite [32, 33], and alunite [34]. Extensive research have shown that the point of zero charge $\left(\mathrm{pH}_{\mathrm{pzc}}\right)$ significantly influence the adsorption properties of the type of clay [35]. It determines the surface charge as well as the cation exchange capacity of the clay material. In this work, we report the purification and characterization of three muscovite clay samples extracted from the eastern and central regions of Ghana for the adsorption of chlorosubstituted phenols and representative dyes from aqueous solutions. Extensive review of related literature has shown that there is no information available in this regard.

\section{Materials and Methods}

2.1. Sample Treatment. Raw clay samples E1 and E2 were collected from the eastern region, while $\mathrm{C} 1$ was obtained from the central region of Ghana. The samples were then transferred to clean polyethylene bags in the laboratory for further analyses. In the lab, foreign materials such as stones, roots, and dead insects were separated, and the samples were ground using porcelain mortar and pestle. $1.00 \mathrm{~kg}$ of each clay sample was suspended in $10 \mathrm{~L}$ of distilled water and homogenized using a mechanical stirrer. The suspension was then left to sediment for 24 hours after which the fine clay particles settled due to gravitation. The clear supernatant and the upper gritty layer were then discarded. The process was repeated for three more times to obtain a pure clay sample for the work. The purified clay samples were air dried and subsequently oven dried at $105^{\circ} \mathrm{C}$ for 24 hours. They were then calcined at $500^{\circ} \mathrm{C}$ for 4 hours to ensure the breakdown of volatile organic compounds and carbonaceous materials.

2.2. Characterization. The cation exchange capacity (CEC) of the clay samples was determined by the ammonium acetate method [36]. The point of zero charge (PZC) was also determined by the salt addition method $[35,37]$ in the $\mathrm{pH}$ range 4-9.

Powder X-ray diffraction patterns of the samples were obtained with a Panalytical Empyrean Powder X-ray Diffractometer $\quad(\mathrm{CuK} \alpha 1=1.541 \AA, \quad \mathrm{CuK} \alpha 2=1.544 \AA$, $\mathrm{CuK} \beta=1.392 \AA$, step scan size of $0.03^{\circ}$ from $5.015^{\circ}$ to $69.965^{\circ}$ at $25^{\circ} \mathrm{C}$ ). The samples were prepared by pressing composite samples with a flat surface down the sample cells. This ensured that the samples were densely packed and randomly oriented. The diffraction patterns were drawn from the data using Spectragryph [38]. The composition of the samples was determined using the MAUD software [39, 40].

The morphology of the samples was studied using images generated by JEOL JSM-6390LV Scanning Electron Microscope (SEM). A single layer of each sample was mounted on a stub using a double-sided adhesive carbon sheets. The magnification used was 500 for samples C1, 250 for E2, and 1200 for E1.

Fourier transform infrared spectroscopy (FT-IR) was carried out on a PerkinElmer UATR Two FT-IR spectrometer over a spectral region of $4000-400 \mathrm{~cm}^{-1}$ with a resolution of $1 \mathrm{~cm}^{-1}$. The samples were analyzed in the form of powders without further dilutions.

\subsection{Adsorption Experiment. Stock solutions of the re-} spective adsorbates were prepared in methanol $(100 \mathrm{mg} / \mathrm{L})$. Working solutions were then prepared by appropriately diluting the stock solution with distilled water to get the adsorbates into aqueous solutions since the chlorophenols are insoluble in water (but the methanolic solution is soluble in water). For the batch adsorption studies, $0.5 \mathrm{~g}$ of each clay sample was added to $50 \mathrm{~mL}$ of aqueous solution of the adsorbate $(5 \mathrm{mg} / \mathrm{L})$. The mixture was stirred with a magnetic stirrer at $300 \mathrm{rpm}$. Exactly $5 \mathrm{~mL}$ of the samples was withdrawn after two hours, filtered, and the absorbance measured with a Shimadzu T70 UV-Vis spectrometer at predetermined wavelengths of maximum absorption $\left(\lambda_{\max }\right) \quad($ phenol $=280 \mathrm{~nm}, \quad 2$-chlorophenol $=275 \mathrm{~nm}, \quad 3-$ chlorophenol $=300 \mathrm{~nm}$, 4-chlorophenol $=260 \mathrm{~nm}$, methyl orange $=440 \mathrm{~nm}$, and Eriochrome Black $\mathrm{T}=200 \mathrm{~nm}$ ). All the experiments were carried out at $303 \mathrm{~K}$ in a temperaturecontrolled water bath. 


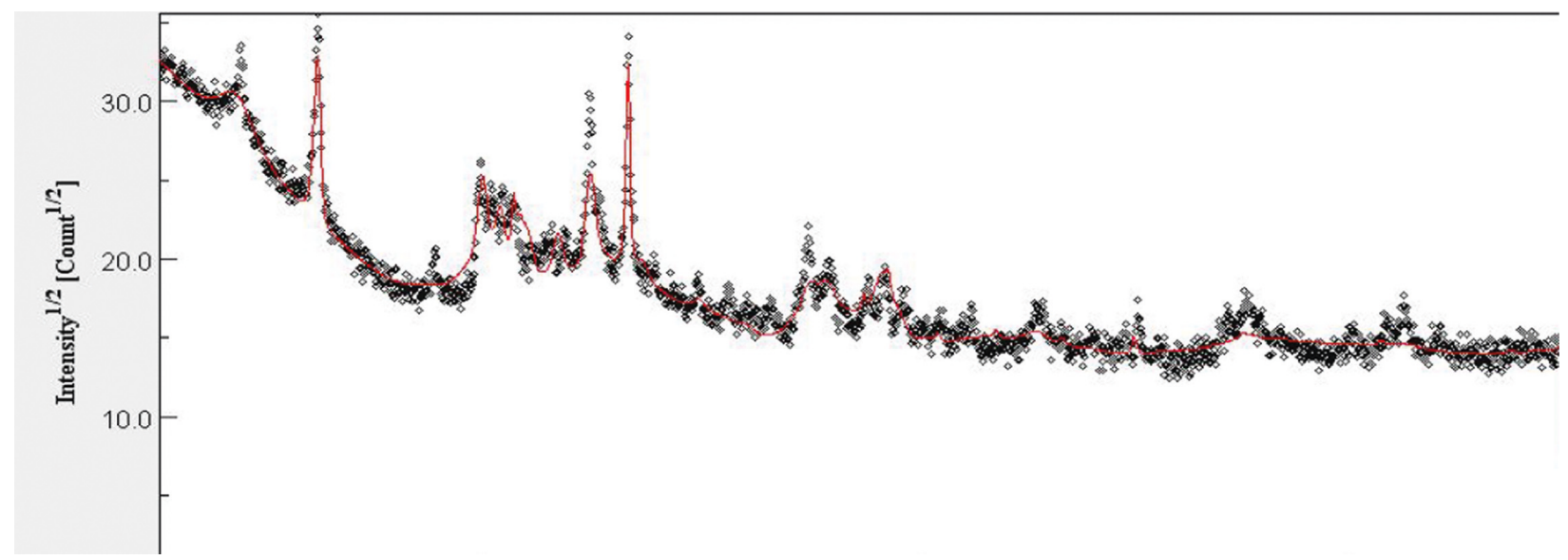

(a)

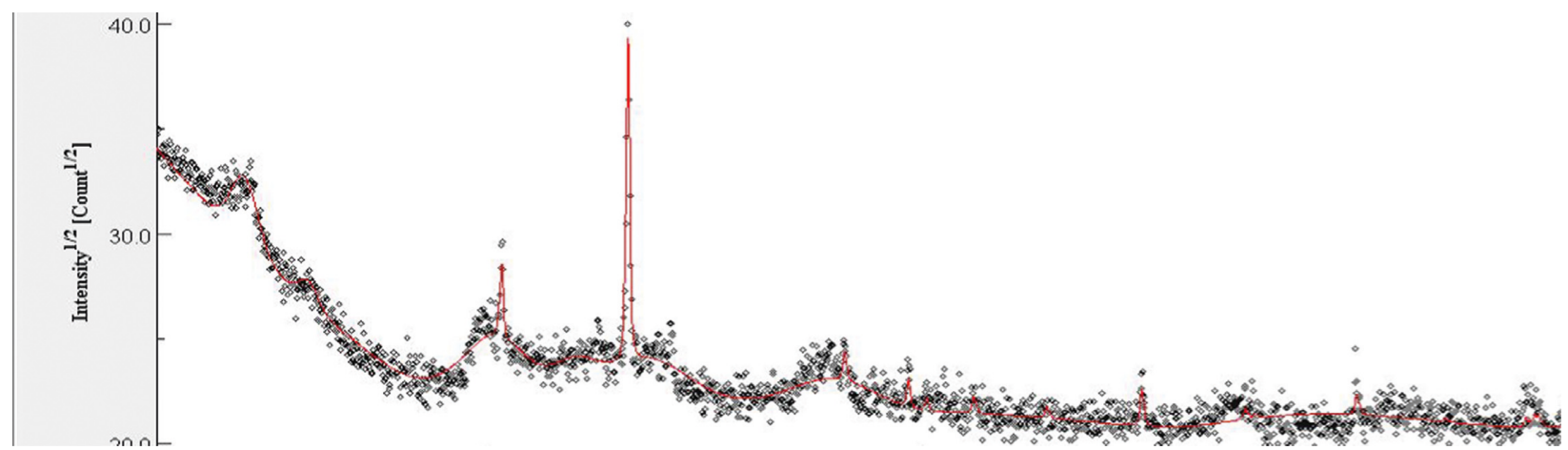

(b)

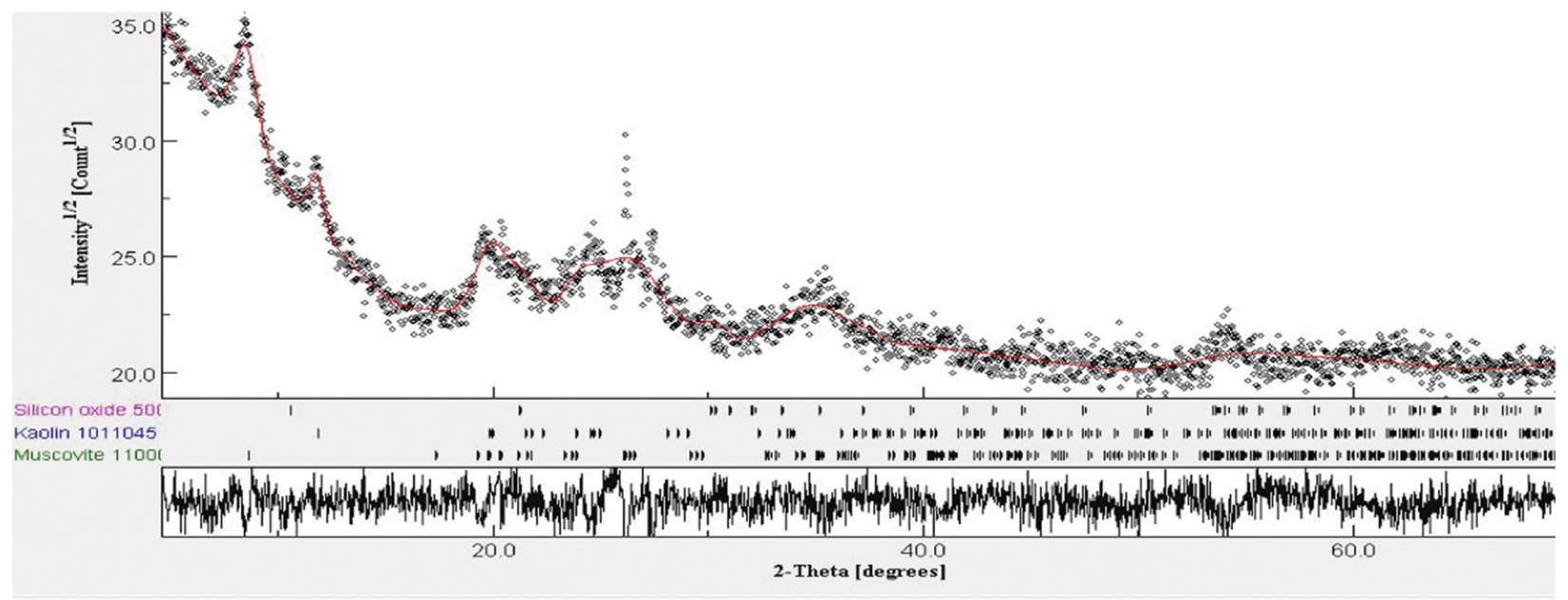

(c)

Figure 1: Powder X-ray diffraction pattern of the clay samples. (a) C1, (b) E1, and (c) E2.

\section{Results and Discussion}

Figure 1 shows the diffractograms of the $\mathrm{X}$-ray diffraction pattern as well as the curve fitting patterns of the clay samples. This was done to elucidate the composition of the samples. All the patterns display the characteristic peak at $2 \theta=26.57^{\circ}$ associated with silicon dioxide. Other conspicuous peaks include $2 \theta=8.83^{\circ}$ for muscovite and $2 \theta=12.37^{\circ}$ for kaolinite.
As shown in Table 1, muscovite was highest in all the samples with proportions of $82.71,89.84$, and $91.33 \%$ for C1, $\mathrm{E} 1$, and E2, respectively, followed by kaolinite and silicon dioxide.

Typical kaolinite and muscovite vibrational frequencies were observed in all the samples. These include conspicuous sharp doublets at 3694 and $3622 \mathrm{~cm}^{-1}$ in C1. These peaks were however weaker in E1 and E2. These bands arise as a result of interlayer $\mathrm{O}-\mathrm{H}$ stretches within the clay structure 
TABLe 1: Peak position and percent composition of the clay samples.

\begin{tabular}{|c|c|c|c|c|c|}
\hline Sample & Peak position $(2 \theta)$ & Intensity (counts) & (\%) Muscovite & (\%) Kaolinite & (\%) Silicon dioxide \\
\hline \multirow{3}{*}{$\mathrm{C} 1$} & 26.62 & 1136 & \multirow{3}{*}{82.71} & \multirow{3}{*}{14.18} & \multirow{3}{*}{3.11} \\
\hline & 8.85 & 1058 & & & \\
\hline & 12.34 & 1251 & & & \\
\hline \multirow{3}{*}{ E1 } & 26.62 & 1654 & \multirow{3}{*}{89.84} & \multirow{3}{*}{4.67} & \multirow{3}{*}{5.49} \\
\hline & 8.58 & 1066 & & & \\
\hline & 12.03 & 762 & & & \\
\hline \multirow{3}{*}{ E2 } & 26.62 & 900 & \multirow{3}{*}{91.33} & \multirow{3}{*}{7.11} & \multirow{3}{*}{1.56} \\
\hline & 8.94 & 1231 & & & \\
\hline & 12.25 & 836 & & & \\
\hline
\end{tabular}

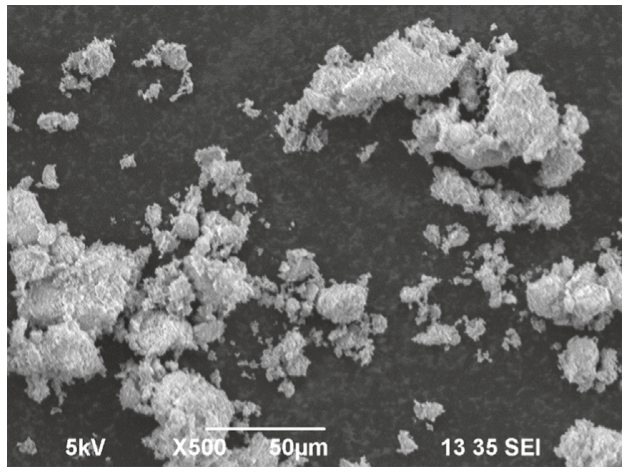

(a)

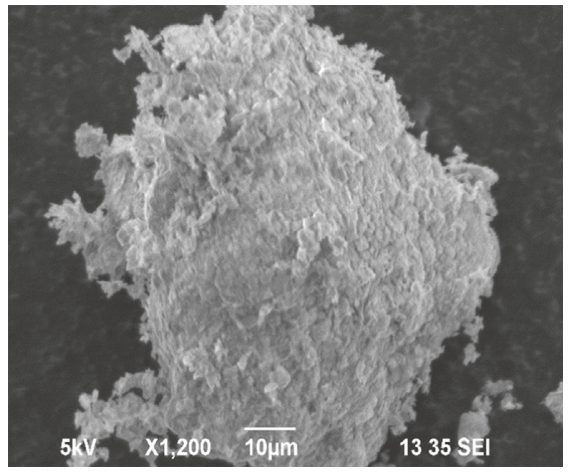

(b)

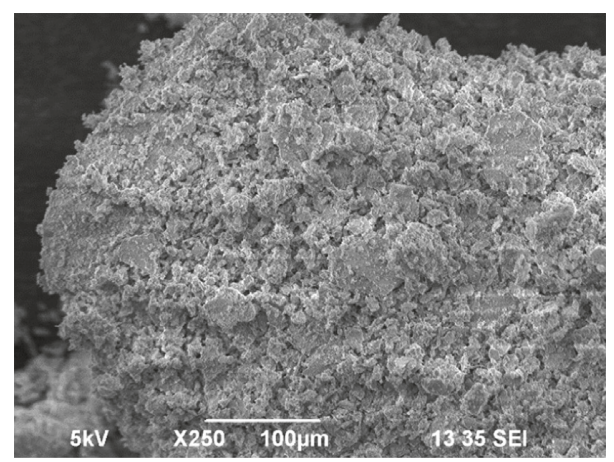

(c)

Figure 2: SEM micrographs of the clay samples. (a) E1, (b) C1, and (c) E2.

[41-43]. Broad peaks at $3404 \mathrm{~cm}^{-1}$ in E1 and E2 can be assigned to stretching of the hydroxyl group in adsorbed water molecules [44]. Strong O-H deformation bands of kaolinites were also observed at 912 and $911 \mathrm{~cm}^{-1}$ with typical Si-O stretching vibrations around $1002-1029 \mathrm{~cm}^{-1}$ in all the samples [41]. Si-O-Al stretching bands were also identified at 550, 667, and $531 \mathrm{~cm}^{-1}$ in $\mathrm{E} 2, \mathrm{E} 1$, and $\mathrm{C} 1$, respectively. According to Vaculikova and Plevova, vibrational peaks at $3622,3436,1026,910$, and $525 \mathrm{~cm}^{-1}$ are characteristic of muscovite clays with a confirmatory peak at 3698 attributable to kaolinites [42]. Therefore, the results of FT-IR data are important in the characterization of clay minerals. The surface topography of the samples was further studied by scanning electron microscopy.

Figure 2 shows the crystalline structure and orientation of the particle sizes making up the clay materials at X500 magnification for samples C1, X250 for E2, and X1200 for E1. These micrographs show some clay platelets of varying sizes arranged in various patterns.

In the determination of the point of zero charge, $\mathrm{NaNO}_{3}$ was added to the clay suspensions to maintain a constant ionic strength. The changes in $\mathrm{pH}$ at fixed ionic strength were then measured as shown in Figure 3. The structural properties of clay minerals make them suitable as charge carriers and form the basis of cation exchange and the swelling ability of these minerals. The charge usually exists as structural or surface charge. The structural charge exists inbetween the octahedral sheets and is permanent while the surface charge depends on the hydrolysis of $\mathrm{Si}-\mathrm{OH}$ and Al$\mathrm{OH}$ bonds along the surface of the clay structure and is $\mathrm{pH}$ dependent. Therefore, the net charge can either be positive or negative. The point of zero charge $\left(\mathrm{pH}_{\mathrm{pzc}}\right)$ is the $\mathrm{pH}$ of the 


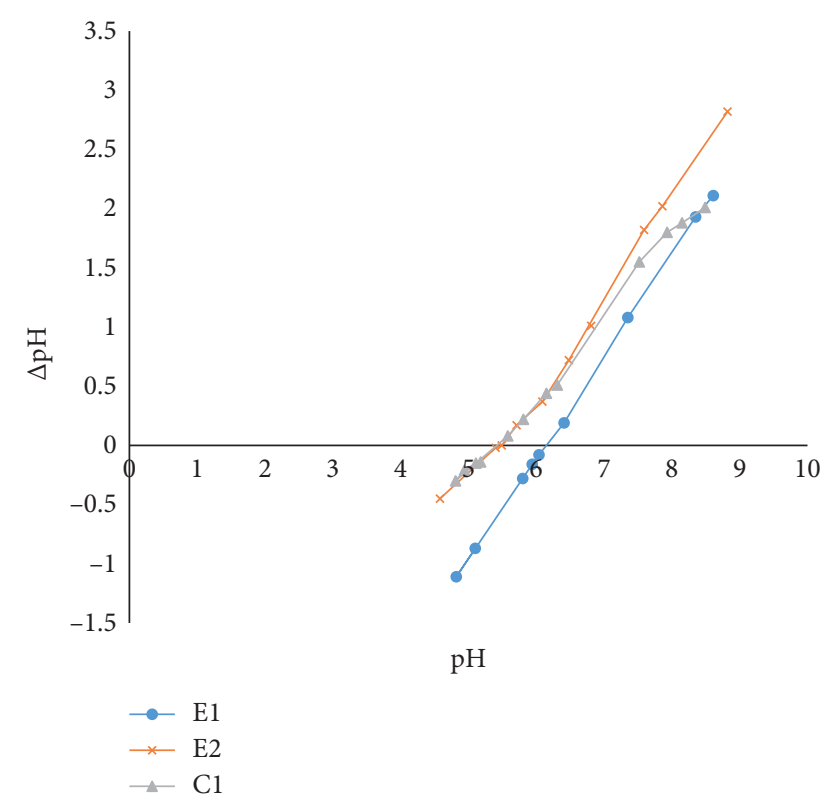

Figure 3: Point of zero charge $\left(\mathrm{pH}_{\mathrm{pzc}}\right)$ of the respective clay samples.

clay suspension at which the net surface charge is zero. It determines how easily a pollutant can be adsorbed onto the surface of the clay. From Figure 3 , the $\mathrm{pH}_{\mathrm{pzc}}$ of samples $\mathrm{C} 1$ and E2 was 5.6, whereas that of E1 was 6.4. According to Mahmood et al., $\mathrm{pH}_{\mathrm{pzc}}$ values are often divergent and no sample has a fixed $\mathrm{pH}_{\mathrm{pzc}}$ value [35]. Similar reports by Schindler et al. [45] and Weiland and Stumm [46] show that the $\mathrm{pH}_{\mathrm{pzc}}$ for kaolin varies from 4.0 to 7.5 and that for illite clay from 2.5 to 8.0. These differences have been attributed to the differences in the origin of the minerals and the methods used [35]. Nonetheless, the surface charge gives an indication of the type of pollutant that can be adsorbed onto the surface of the clay mineral [47]. The values recorded in Figure 3 show that the surface charge of the clay samples is generally positive and can adsorb negative species.

Cation exchange capacity is a measure of the clay mineral to substitute unfixed cations in the interlayer and surface layers for cations in solution. It expresses the ability of clay to adsorb pollutants such as heavy metals, phenols, dyes, and biocides.

Most common cations found in exchangeable positions include $\mathrm{Ca}^{2+}, \mathrm{Mg}^{2+}, \mathrm{Na}^{+}$, and $\mathrm{K}^{+}$. From Table 2, $\mathrm{Ca}^{2+}$ and $\mathrm{Mg}^{2+}$ were the dominant exchangeable ions in all the clay samples with $\mathrm{K}^{+}$being the least.

3.1. Adsorption Studies. The $\mathrm{pH}_{\mathrm{pzc}}$ is an important factor that determines the surface active centers and the types of adsorbates that a clay sample can adsorb. The $\mathrm{pH}_{\mathrm{pzc}}$ values shown in Figure 3 illustrate the cationic nature of the clay surfaces. The lower the $\mathrm{pH}_{\mathrm{pzc}}$, the more cationic the surface layer of the clay, making it susceptible to adsorb anionic pollutants [48].

Figure 4 shows the time-dependent adsorption kinetics of phenols on the different clay samples. Generally, the clay
TABLE 2: Concentration $(\mathrm{cmol} / \mathrm{kg}$ ) of exchangeable ions in the clay samples.

\begin{tabular}{lccc}
\hline ion & \multicolumn{3}{c}{ Sample } \\
& $\mathrm{C} 1$ & $\mathrm{E} 1$ & $\mathrm{E} 2$ \\
\hline $\mathrm{Ca}^{2+}$ & 0.880 & 13.204 & 2.600 \\
$\mathrm{Mg}^{2+}$ & 0.480 & 2.841 & 1.560 \\
$\mathrm{Na}^{+}$ & 0.314 & 0.377 & 0.377 \\
$\mathrm{~K}^{+}$ & 0.064 & 0.077 & 0.077 \\
\hline
\end{tabular}

samples were very efficient in removing 4-chlorophenol. The high adsorption capacity of $\mathrm{C} 1$ is attributable to the high content (14.18\%) of kaolinite as shown in Table 1. According to Dogan et al. [49], the 1:1 aluminosilicate structure of kaolinite clay carries a small negative charge as a result of the isomorphous substitution of $\mathrm{Si}^{4+}$ by $\mathrm{Al}^{3+}$, leaving a slight negative charge for each substitution $[49,50]$. The presence of this slight negative charge increases the electron density on the clay surface thereby facilitating the interaction between the clay surface and the phenolic hydrogen [51]. Phenols however appear to be amphoteric with the phenolic $-\mathrm{OH}$ acting as a hydrogen bond donor/acceptor in its interactions. This property of phenols makes the adsorption complex under different experimental conditions [52]. The slopes of the curves were however similar indicating that the position of the chloro-substituent has little effect on the rate of adsorption of the phenols onto the clay sample [53].

The adsorption kinetics of Eriochrome Black $\mathrm{T}$ (a phenolic dye) and methyl orange (an anionic dye) are shown in Figure 5.

It is evident that methyl orange is better adsorbed than Eriochrome Black T. This can partly be attributed to the cationic surface charge of the clay which has higher affinity for the anionic methyl orange. Similar studies by Nishimura et al. showed the adsorption propensity of dodecylammonium amine surfactants at muscovite-water interfaces [54].

\section{Conclusion}

Three clay samples (E1, E2, and C1) extracted from different parts of Ghana have been purified and characterized. Powder X-ray diffraction data shows that the samples were predominantly muscovite with the following compositions: E1 (89.84\% muscovite, $4.67 \%$ kaolinite, and 5.59\% $\mathrm{SiO}_{2}$ ), E2 (91.33\% muscovite, $7.11 \%$ kaolinite, and $1.56 \% \mathrm{SiO}_{2}$ ), and C1 (82.71\% muscovite, $14.18 \%$ kaolinite, and $3.11 \% \mathrm{SiO}_{2}$ ). The composition was confirmed by comparing with characteristic peaks in the FT-IR spectrum of standard clay samples. Surface characterization by scanning electron microscopy revealed crystalline morphology of the samples which are suitable for adsorption studies. The cation exchange capacity was determined by the ammonium acetate method, and $\mathrm{Ca}^{2+}$ and $\mathrm{Mg}^{2+}$ were found as the most exchangeable cations. The surface was further characterized by the salt addition method to determine the point of zero charge $\left(\mathrm{pH}_{\mathrm{pzc}}\right)$. The surfaces were found to be slightly cationic with $\mathrm{pH}_{\mathrm{pzc}}$ 5.58-6.40. Time-dependent adsorption studies show that $\mathrm{C} 1$ is a good candidate for the adsorption of chlorophenols, methyl orange, and Eriochrome Black T. 


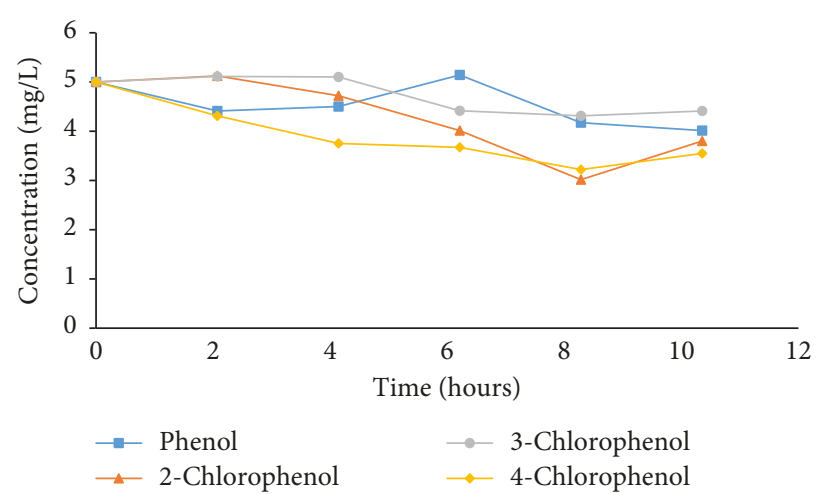

(a)

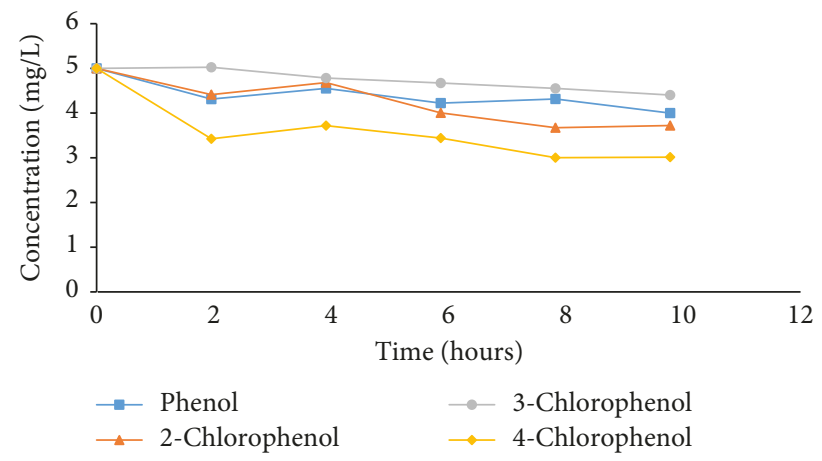

(b)

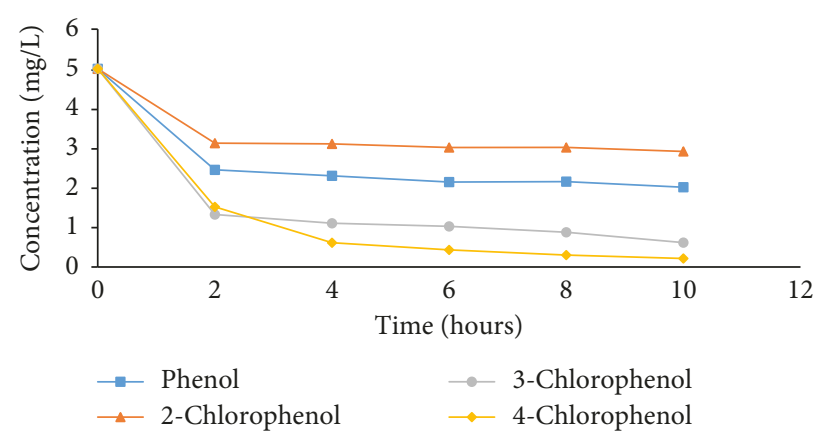

(c)

Figure 4: Time-dependent adsorption kinetics of phenols on the clay samples. (a) E1, (b) E2, and (c) C1.

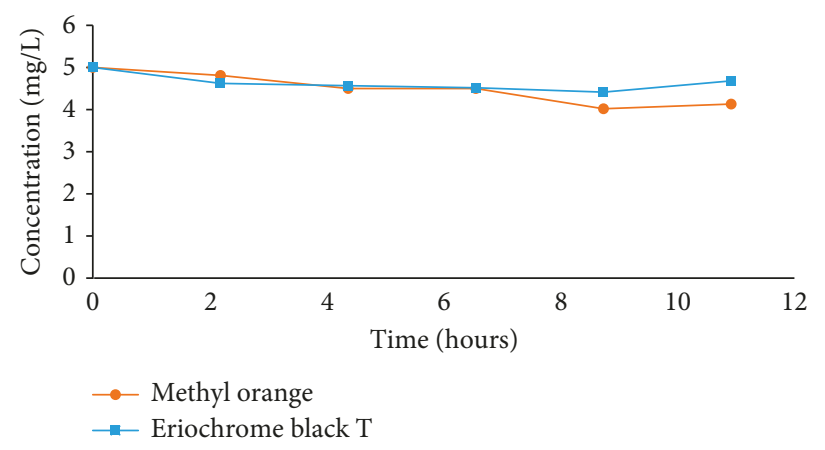

(a)

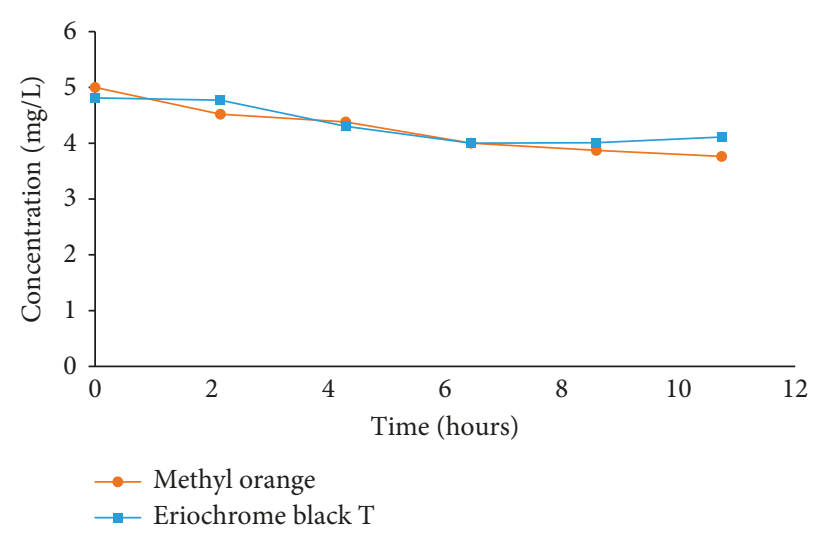

(b)

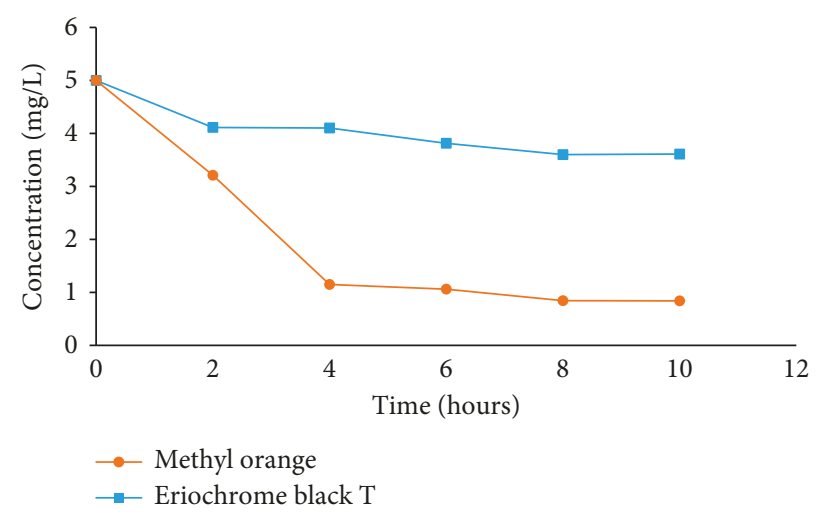

(c)

Figure 5: Time-dependent adsorption kinetics of Eriochrome Black T and methyl orange on the clay samples. (a) E1, (b) E2, and (c) C1. 


\section{Data Availability}

The data used to support the findings of this study are available from the corresponding author upon request.

\section{Conflicts of Interest}

The authors declare that there are no conflicts of interest regarding the preparation and publication of this manuscript.

\section{Acknowledgments}

The authors are grateful to Professor V. P. Y. Gadzepko for providing clay samples for this work.

\section{References}

[1] J. Eriksson, S. Rahm, N. Green, Å. Bergman, and E. Jakobsson, "Photochemical transformations of tetrabromobisphenol A and related phenols in water," Chemosphere, vol. 54 , no. 1 , pp. 117-126, 2004.

[2] R. Vinu and G. Madras, "Kinetics of simultaneous photocatalytic degradation of phenolic compounds and reduction of metal ions with nano- $\mathrm{TiO}_{2}$," Environmental Science \& Technology, vol. 42, no. 3, pp. 913-919, 2007.

[3] F. A. Tomás-Barberán and J. C. Espin, "Phenolic compounds and related enzymes as determinants of quality in fruits and vegetables," Journal of the Science of Food and Agriculture, vol. 81, no. 9, pp. 853-876, 2001.

[4] P. S. Murthy and M. M. Naidu, "Recovery of phenolic antioxidants and functional compounds from coffee industry by-products," Food and Bioprocess Technology, vol. 5, no. 3, pp. 897-903, 2012.

[5] K. Lee, K. Yoon, J. Kim, J. Bae, J. Yang, and S. Hong, "Effect of novolac phenol and oligomeric aryl phosphate mixtures on flame retardance enhancement of ABS," Polymer Degradation and Stability, vol. 81, no. 1, pp. 173-179, 2003.

[6] N. Dieme, "Influence of a semiconductor gap's energy on the electrical parameters of a parallel vertical junction photocell," Energy and Power Engineering, vol. 7, no. 5, pp. 203-208, 2015.

[7] M. Kitis, "Disinfection of wastewater with peracetic acid: a review," Environment International, vol. 30, no. 1, pp. 47-55, 2004.

[8] Y. Liu, B. Wen, and X. Q. Shan, "Determination of pentachlorophenol in wastewater irrigated soils and incubated earthworms," Talanta, vol. 69, no. 5, pp. 1254-1259, 2006.

[9] J. Michałowicz and W. Duda, "Phenols-sources and toxicity," Polish Journal of Environmental Studies, vol. 16, no. 3, pp. 347-362, 2007.

[10] H. B. Senturk, D. Ozdes, A. Gundogdu, C. Duran, and M. Soylak, "Removal of phenol from aqueous solutions by adsorption onto organomodified Tirebolu bentonite: equilibrium, kinetic and thermodynamic study," Journal of Hazardous Materials, vol. 172, no. 1, pp. 353-362, 2009.

[11] M. Ahmaruzzaman, "Adsorption of phenolic compounds on low-cost adsorbents: a review," Advances in colloid and Interface science, vol. 143, no. 1-2, pp. 48-67, 2008.

[12] M. Bucheli-Witschel and T. Egli, "Environmental fate and microbial degradation of aminopolycarboxylic acids," FEMS Microbiology Reviews, vol. 25, no. 1, pp. 69-106, 2001.

[13] A. Maleki, A. Mahvi, F. Vaezi, and N. R. Nabizadeh, "Ultrasonic degradation of phenol and determination of the oxidation by-products toxicity," Iranian Association of Environmental Health, vol. 2, no. 3, pp. 201-206, 2005.

[14] B. Bolto and J. Gregory, "Organic polyelectrolytes in water treatment," Water Research, vol. 41, no. 11, pp. 2301-2324, 2007.

[15] S. K. Dentel, "Coagulant control in water treatment," Critical Reviews in Environmental Science, vol. 21, no. 1, pp. 41-135, 1991.

[16] C. Y. Teh, P. M. Budiman, K. P. Y. Shak, and T. Y. Wu, "Recent advancement of coagulation-flocculation and its application in wastewater treatment," Industrial \& Engineering Chemistry Research, vol. 55, no. 16, pp. 4363-4389, 2016.

[17] V. Kavitha and K. Palanivelu, "The role of ferrous ion in Fenton and photo-Fenton processes for the degradation of phenol," Chemosphere, vol. 55, no. 9, pp. 1235-1243, 2004.

[18] B. Iurascu, I. Siminiceanu, D. Vione, M. Vicente, and A. Gil, "Phenol degradation in water through a heterogeneous photoFenton process catalyzed by Fe-treated laponite," Water Research, vol. 43, no. 5, pp. 1313-1322, 2009.

[19] R. F. Pontes, J. E. Moraes, A. Machulek Jr., and J. M. Pinto, “A mechanistic kinetic model for phenol degradation by the Fenton process," Journal of Hazardous Materials, vol. 176, no. $1-3$, pp. 402-413, 2010.

[20] G. C. Yang and Y. W. Long, "Removal and degradation of phenol in a saturated flow by in-situ electrokinetic remediation and fenton-like process," Journal of Hazardous Materials, vol. 69, no. 3, pp. 259-271, 1999.

[21] I. S. Chang and S. N. Kim, "Wastewater treatment using membrane filtration-effect of biosolids concentration on cake resistance," Process Biochemistry, vol. 40, no. 3-4, pp. 1307-1314, 2005.

[22] A. Dąbrowski, P. Podkościelny, Z. Hubicki, and M. Barczak, "Adsorption of phenolic compounds by activated carbon-a critical review," Chemosphere, vol. 58, no. 8, pp. 1049-1070, 2005.

[23] I. Tan, A Ahmad, and B. Hameed, "Adsorption of basic dye on high-surface-area activated carbon prepared from coconut husk: Equilibrium, kinetic and thermodynamic studies," Journal of Hazardous Materials, vol. 154, no. 1-3, pp. 337-346, 2008.

[24] A. Gürses, Ç. Doğar, M. Yalçın, M. Açıkyıldız, R. Bayrak, and S. Karaca, "The adsorption kinetics of the cationic dye, methylene blue, onto clay," Journal of Hazardous Materials, vol. 131, no. 1-3, pp. 217-228, 2006.

[25] A. Kurniawan, H. Sutiono, Y. H. Ju et al., "Utilization of rarasaponin natural surfactant for organo-bentonite preparation: application for methylene blue removal from aqueous effluent," Microporous and Mesoporous Materials, vol. 142, no. 1, pp. 184-193, 2011.

[26] M. Hajjaji and H. El Arfaoui, "Adsorption of methylene blue and zinc ions on raw and acid-activated bentonite from Morocco," Applied Clay Science, vol. 46, no. 4, pp. 418-421, 2009.

[27] A. Tabak, N. Baltas, B. Afsin, M. Emirik, B. Caglar, and E. Eren, "Adsorption of reactive red 120 from aqueous solutions by cetylpyridinium-bentonite," Journal of Chemical Technology \& Biotechnology, vol. 85, no. 9, pp. 1199-1207, 2010.

[28] S. F. P. Yesi, Y. H. Ju, F. E. Soetaredjo, and S. Ismadji, "Adsorption of acid blue 129 from aqueous solutions onto raw and surfactant-modified bentonite: application of temperaturedependent forms of adsorption isotherms," Adsorption Science \& Technology, vol. 28, no. 10, pp. 847-868, 2010. 
[29] S. Bouzid, A. Khenifi, K. Bennabou, R. Trujillano, M. Vicente, and Z. Derriche, "Removal of orange II by phosphoniummodified Algerian bentonites," Chemical Engineering Communications, vol. 202, no. 4, pp. 520-533, 2015.

[30] F. Priscila, Z. M. Magriotis, M. A. Rossi, R. F. Resende, and C. A. Nunes, "Optimization by response surface methodology of the adsorption of coomassie blue dye on natural and acidtreated clays," Journal of Environmental Management, vol. 130, pp. 417-428, 2013.

[31] H. Chen and J. Zhao, "Adsorption study for removal of Congo red anionic dye using organo-attapulgite," Adsorption, vol. 15, no. 4, pp. 381-389, 2009.

[32] D. Chen, J. Chen, X. Luan, H. Ji, and Z. Xia, "Characterization of anion-cationic surfactants modified montmorillonite and its application for the removal of methyl orange," Chemical Engineering Journal, vol. 171, no. 3, pp. 1150-1158, 2011.

[33] S. Yang, M. Gao, and Z. Luo, "Adsorption of 2-Naphthol on the organo-montmorillonites modified by Gemini surfactants with different spacers," Chemical Engineering Journal, vol. 256 , pp. 39-50, 2014.

[34] S. Tunali Akar, T. Alp, and D. Yilmazer, "Enhanced adsorption of acid Red 88 by an excellent adsorbent prepared from alunite," Journal of Chemical Technology \& Biotechnology, vol. 88, no. 2, pp. 293-304, 2013.

[35] T. Mahmood, M. T. Saddique, A. Naeem, P. Westerhoff, S. Mustafa, and A. Alum, "Comparison of different methods for the point of zero charge determination of NiO," Industrial \& Engineering Chemistry Research, vol. 50, no. 17, pp. 10017-10023, 2011.

[36] K. P. Kitsopoulos, "Cation-exchange capacity (CEC) of zeolitic volcaniclastic materials: applicability of the ammonium acetate saturation (AMAS) method," Clays and Clay Minerals, vol. 47, no. 6, pp. 688-696, 1999.

[37] M. Kosmulski, "pH-dependent surface charging and points of zero charge. IV. Update and new approach," Journal of Colloid and Interface Science, vol. 337, no. 2, pp. 439-448, 2009.

[38] F. Menges, Spectragryph-Optical Spectroscopy Software, Version 1.0. 7, Universität Konstanz, Obersdorf, Germany, 2017.

[39] L. Lutterotti, M. Bortolotti, G. Ischia, I. Lonardelli, and H. Wenk, "Rietveld texture analysis from diffraction images," Zeitschrift für Kristallographie Supplements, vol. 2007, no. 26, pp. 125-130, 2007.

[40] S. Matthies, L. Lutteroti, and H. Wenk, "Advances in texture analysis from diffraction spectra," Journal of Applied Crystallography, vol. 30, no. 1, pp. 31-42, 1997.

[41] P. S. Nayak and B. Singh, "Instrumental characterization of clay by XRF, XRD and FTIR," Bulletin of Materials Science, vol. 30, no. 3, pp. 235-238, 2007.

[42] L. Vaculikova and E. Plevova, "Identification of clay minerals and micas in sedimentary rocks," Acta Geodynamica et Geomaterialia, vol. 2, no. 2, p. 163, 2005.

[43] Z. Chen, C. Huang, S. Liu, Y. Zhang, and K. Gong, "Synthesis, characterization and properties of clay-polyacrylate hybrid materials," Journal of Applied Polymer Science, vol. 75, no. 6, pp. 796-801, 2000.

[44] W. Rahmalia, J. F. Fabre, T. Usman, and Z. Mouloungui, "Adsorption characteristics of bixin on acid-and alkali-treated kaolinite in aprotic solvents," Bioinorganic Chemistry and Applications, vol. 2018, pp. 1-9, 2018.

[45] P. Schindler, P. Liechti, and J. Westall, "Adsorption of copper, cadmium and lead from aqueous solution to the kaolinite/ water interface," Journal of Agricultural Science, vol. 35, pp. 219-230, 1987.
[46] E. Wieland and W. Stumm, "Dissolution kinetics of kaolinite in acidic aqueous solutions at $25 \mathrm{C}$," Geochimica et Cosmochimica Acta, vol. 56, no. 9, pp. 3339-3355, 1992.

[47] R. S. Bowman, "Applications of surfactant-modified zeolites to environmental remediation," Microporous and Mesoporous Materials, vol. 61, no. 1-3, pp. 43-56, 2003.

[48] M. T. Yagub, T. K. Sen, S. Afroze, and H. M. Ang, "Dye and its removal from aqueous solution by adsorption: a review," Advances in Colloid and Interface Science, vol. 209, pp. 172184, 2014.

[49] M. Doğan, M. H. Karaoğlu, and M. Alkan, “Adsorption kinetics of maxilon yellow 4GL and maxilon red GRL dyes on kaolinite," Journal of Hazardous Materials, vol. 165, no. 1-3, pp. 1142-1151, 2009.

[50] A. Tehrani-Bagha, H. Nikkar, N. Mahmoodi, M. Markazi, and F. Menger, "The sorption of cationic dyes onto kaolin: Kinetic, isotherm and thermodynamic studies," Desalination, vol. 266, no. 1-3, pp. 274-280, 2011.

[51] Y. B. Acar, H. Li, and R. J. Gale, "Phenol removal from kaolinite by electrokinetics," Journal of Geotechnical Engineering, vol. 118, no. 11, pp. 1837-1852, 1992.

[52] U. F. Alkaram, A. A. Mukhlis, and A. H. Al-Dujaili, "The removal of phenol from aqueous solutions by adsorption using surfactant-modified bentonite and kaolinite," Journal of Hazardous Materials, vol. 169, no. 1-3, pp. 324-332, 2009.

[53] M. Boufatit, H. Ait-Amar, and W. McWhinnie, "Development of an Algerian material montmorillonite clay. adsorption of phenol, 2-dichlorophenol and 2,4,6-trichlorophenol from aqueous solutions onto montmorillonite exchanged with transition metal complexes," Desalination, vol. 206, no. 1-3, pp. 394-406, 2007.

[54] S. Nishimura, P. J. Scales, S. Biggs, and T. W. Healy, "An electrokinetic study of the adsorption of dodecyl ammonium amine surfactants at the muscovite mica- water interface," Langmuir, vol. 16, no. 2, pp. 690-694, 2000. 

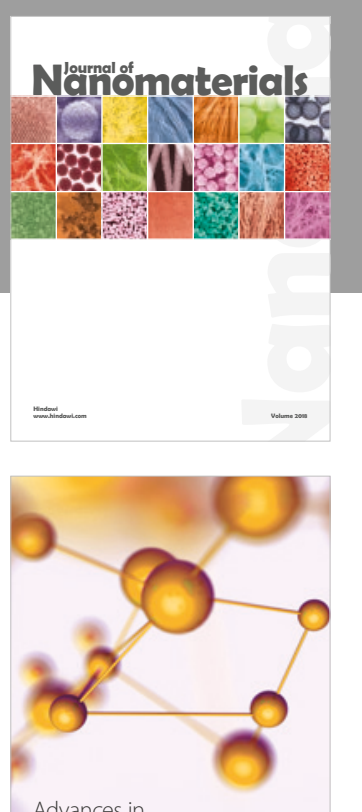

Physical Chemistry
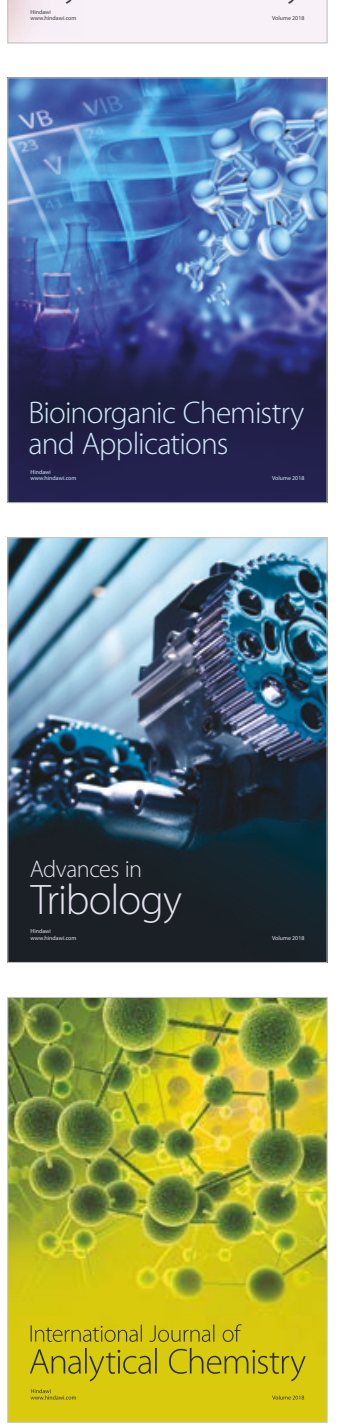

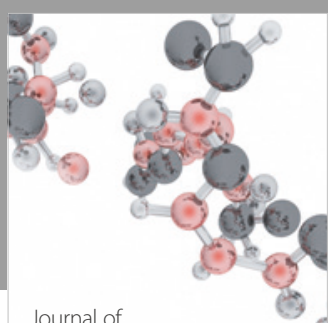

Analytical Methods

in Chemistry

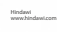

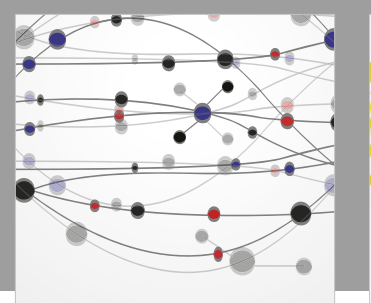

The Scientific World Journal

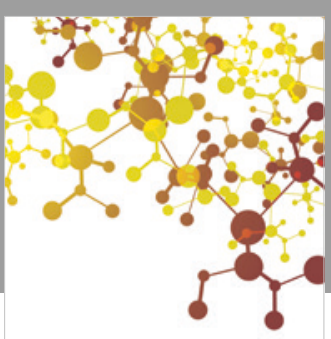

Journal of

Applied Chemistry
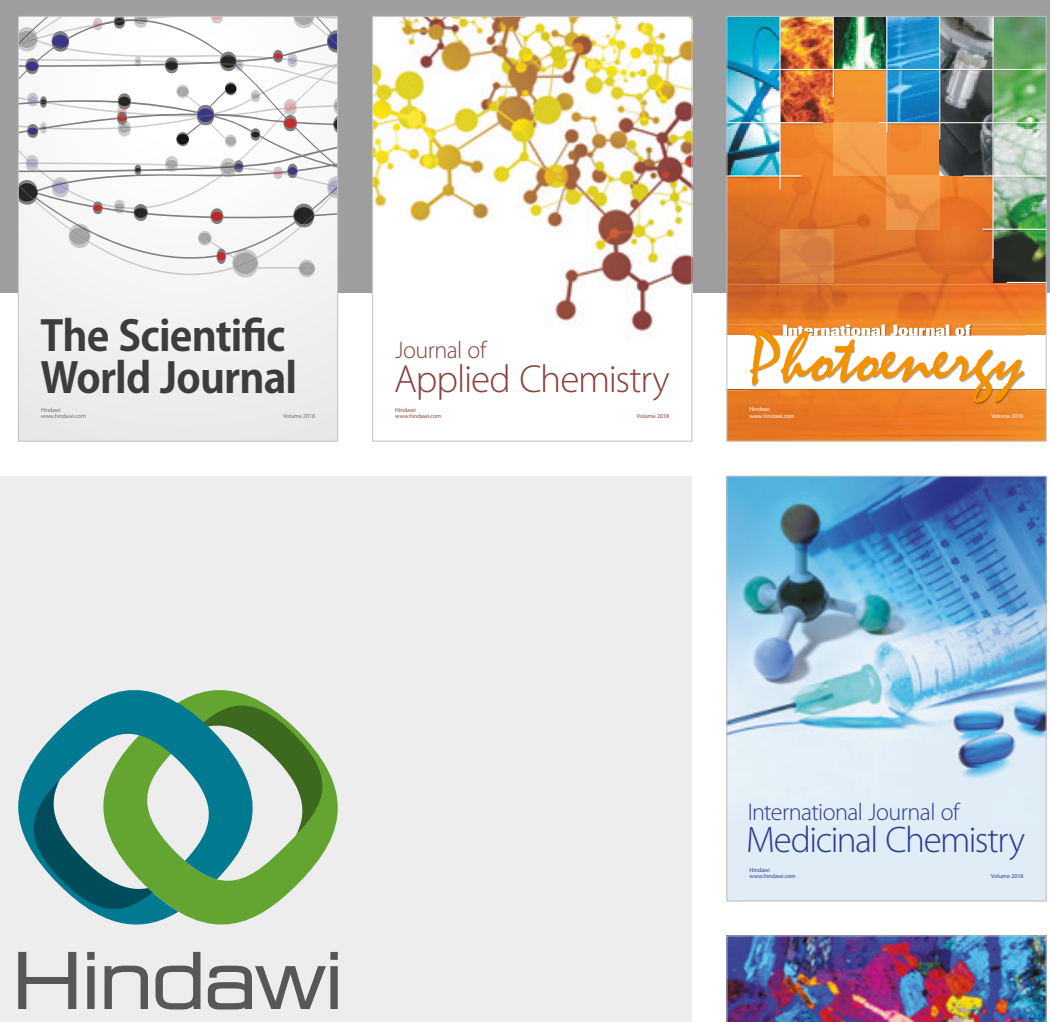

Submit your manuscripts at

www.hindawi.com
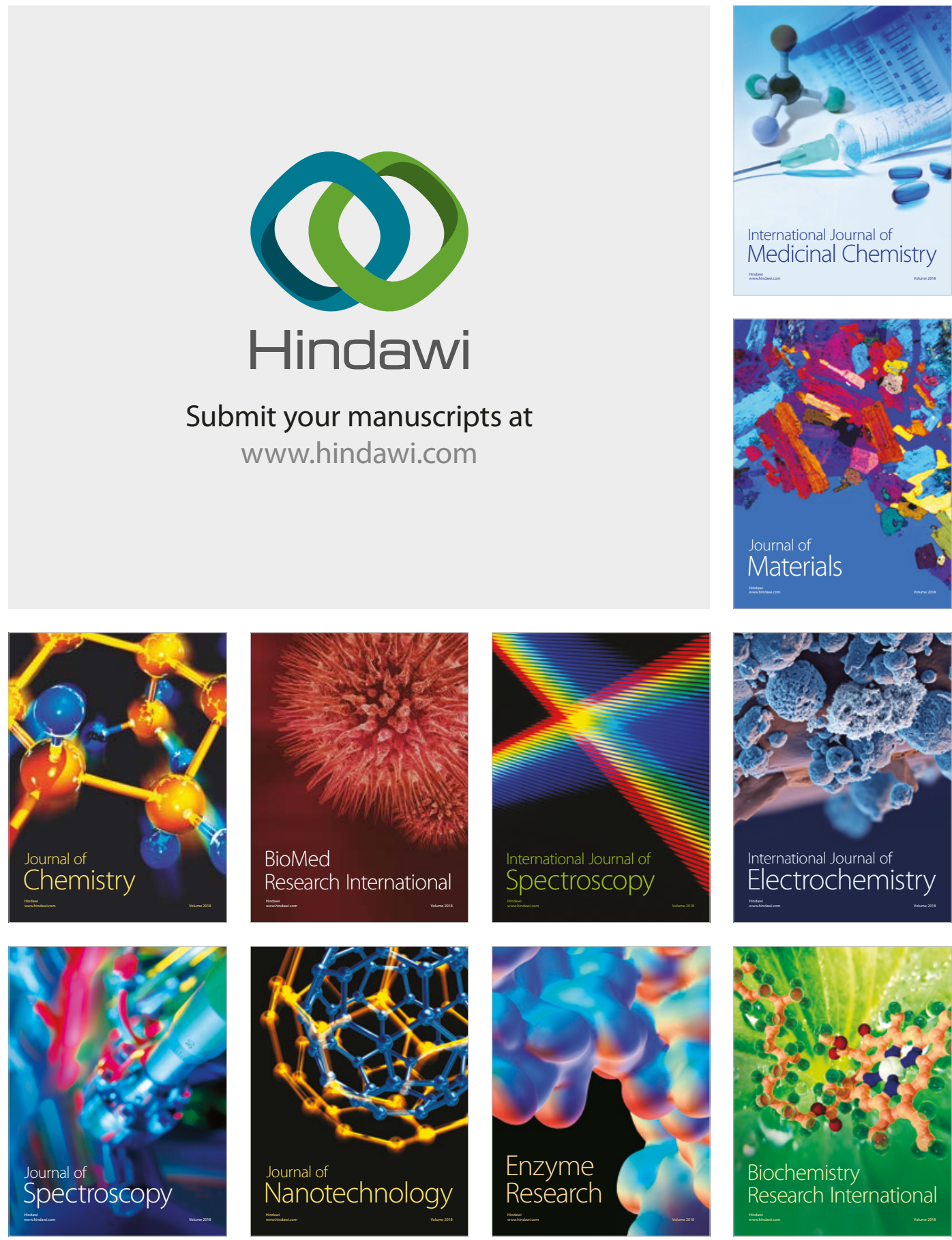
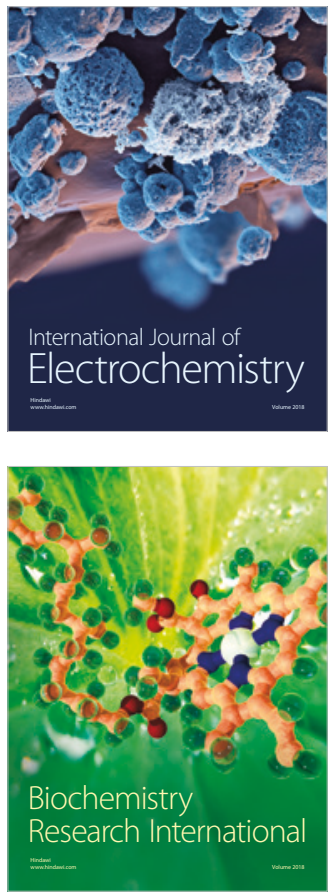